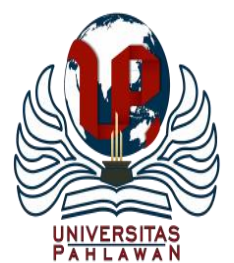

Edukatif : Jurnal Ilmu Pendidikan Volume 3 Nomor 2 Tahun 2021 Halm 314 - 320

EDUKATIF: JURNAL ILMU PENDIDIKAN

Research \& Learning in Education

https://edukatif.org/index.php/edukatif/index

\title{
Efektivitas Layanan Bimbingan Kelompok Berbasis Problem Based Learning untuk Meningkatkan Komunikasi Interpersonal Siswa
}

\author{
Rasimin $^{1 凶}$, Affan Yusra ${ }^{2}$, Hera Wahyuni ${ }^{3}$ \\ FKIP Universitas Jambi ${ }^{1,2,3}$ \\ E-mail : $\underline{\text { Rasimin.fkip@unja.ac.id }}^{1}, \underline{\text { Affan15yusra@unja.ac.id }}^{2}, \underline{\text { herawahyuni@unja.ac.id }}^{3}$
}

\begin{abstract}
Abstrak
Tujuan penelitian ini: 1) Mendeskripsikan kondisi tingkat komunikasi interpersonal siswa kelas XII IPS SMA Negeri 5 Kota Jambi sebelum diberikan perlakuan (pre test). 2) Mendeskripsikan tingkat komunikasi interpersonal siswa kelas XII IPS SMA Negeri 5 Kota Jambi setelah diberikan perlakuan (post test). 3) Menguji keefektifan layanan bimbingan kelompok dengan berbasis Problem based learning efektif untuk meningkatkan komunikasi interpersonal siswa kelas XII IPS SMA Negeri 5 Kota Jambi. Adapun alat bantu yang digunakan dalam penelitian adalah skala komunikasi interpersonal dan pedoman observasi. Jenis pelitian yang digunakan adalah tes pra dan pasca satu kelompok eksperimen. untuk analisis penelitian penggunaan tes dengan taraf signivikansi Wilcoxon $0,05 \%$. Hasil penelitian ini menunjukkan terdapat perbedaan yang lebih kecil dari $0,003<0,05$ Ha dapat disimpulkan kemudian diterima.
\end{abstract}

Kata Kunci: Layanan Bimbingan Kelompok, Problem Based Learning, komunikasi interpersonal.

\section{Abstract}

The purposes of this study are: 1) to describe the condition of the interpersonal communication level of the students of class XII IPS at SMA Negeri 5 Jambi City before being given the treatment (pre test), 2) to describe the level of interpersonal communication among class XII IPS students of SMA Negeri 5 Jambi City after being given treatment (post test), 3) to investigate the effectiveness of group tutoring services based on problem-based learning to improve interpersonal communication among class XII IPS students of SMA Negeri 5 Jambi City. The tools used in the study were interpersonal communication scales and observation guidelines. The research used pre and post test of one experimental group. For the research analysis, it used the test with a Wilcoxon significance level of $0.05 \%$. The results of this study indicate that there is a difference smaller than $0.003<0.05 \mathrm{Ha}$, it can be concluded then accepted.

Keywords: Group Tutoring, Problem based learning, Interpersonal communication.

Copyright (c) 2021 Rasimin, Affan Yusra, Hera Wahyuni

$\triangle$ Corresponding author

Email : Rasimin.fkip@unja.ac.id

DOI $\quad$ : https://doi.org/10.31004/edukatif.v3i2.261

ISSN 2656-8063 (Media Cetak)

ISSN 2656-8071 (Media Online)

Edukatif : Jurnal Ilmu Pendidikan Vol 3 No 2 Tahun 2021 p-ISSN 2656-8063 e-ISSN 2656-8071 
315 Efektivitas Layanan Bimbingan Kelompok Berbasis Problem Based Learning untuk Meningkatkan

Komunikasi Interpersonal Siswa - Rasimin, Affan Yusra, Hera Wahyuni

DOI: https://doi.org/10.31004/edukatif.v3i2.261

\section{PENDAHULUAN}

Manusia sebagai bagian bumi yang paling sempurna dengan segala potensinya, harus mampu menggunakan segala potensi yang dimiliki manusia untuk menjalani hidup dengan baik dan memperoleh kebahagiaan. Al-Syaibany dalam (Hasbi Siddik, 2016) menyatakan bahwa manusia adalah makhluk yang dianggap paling berharga. Hal tersebut didasari oleh kemampuan manusia yang dapat berpikir dan memiliki tubuh 3 dimensi yaitu akal dan roh. Perkembangan manusia dan pertumbuannya selalu dipengaruhi oleh lingkungan tempat tinggalnya.

Laki-laki dalam hidupnya dapat mencapai kebahagiaan dan mengaktualisasikan diri, ketika manusia sedang melalui proses pencapaian tersebut akan menemui masalah dan hambatan, sehingga dalam proses penyelesaian masalah tersebut membutuhkan komunikasi interpersonal individu yang menemukan jalan penyelesaiannya.

Komunikasi interpersonal merupakan salah satu hal yang membantu masyarakat dalam pemecahan masalah dan pengambilan keputusan dalam setiap masalah yang dihadapi. Komunikasi interpersonal dapat membuat hubungan antar manusia menjadi harmonis dan ribut yang menentukan dalam komunikasi interpersonal, perilaku manusia ini dapat terbentuk dalam pendidikan yang sistematis. Hal ini sejalan dengan yang di ungkapkan oleh Singh lairopoii (dalam Khodijah, Suharno dan Triyanti, 2018) menjelaskan komunikasi interpersonal proses penyampaian informasi dan pemahaman dari satu orang ke orang lain, yang sangat penting untuk keberhasilan organisasi.

Berdasarkan UU SISDIKNAS No 20 tahun 2003 pasal 3 mengenai tujuan pendidikan yaitu mencerdaskan kehidupan bangsa dan mengembangkan segenap iman dan taqwa kepada Tuhan Yang Maha Esa dan beretika luhur, memiliki ilmu dan keterampilan, sehat jasmani dan rohani, berkepribadian mantap dan mandiri serta rasa tanggung jawab sipil. Pendidikan pada siswa SMA dituntut aktif, kreatif, dan terampil dalam proses pembelajaran. tujuan pendidikan yaitu mencerdaskan kehidupan bangsa dan mengembangkan segenap iman dan taqwa kepada Tuhan Yang Maha Esa dan beretika luhur, memiliki ilmu dan keterampilan, sehat jasmani dan rohani, berkepribadian mantap dan mandiri serta rasa tanggung jawab sipil. Pendidikan pada siswa SMA dituntut aktif, kreatif, dan terampil dalam proses pembelajaran. Menciptakannya adalah dengan berdebat atau berbicara di kelas ketika diskusi dan bertanya kepada guru ketika mata pelajaran melawan kemajuan, tetapi pada kenyataannya keberanian berbicara atau berdebat di depan umum tidak dimiliki semua siswa.

Sebagian besar siswa belum menyadari bahwa komunikasi antar pribadi tingkat rendah dapat menjadi kendala besar dalam menjalankan aktivitas sehari-hari. Sikap seseorang yang menunjukkan rendahnya kemampuan komunikasi interpersonalnya antara lain kurangnya keterbukaan dalam menyajikan informasi, kurang peduli dengan lingkungan, isolasi, cenderung egois, menolak untuk menerima pendapat orang lain, hal inilah yang menghambat sering kali menghambat seseorang. untuk dapat berkomunikasi dengan baik. Rendahnya tingkat komunikasi interpersonal siswa dapat mengganggu efektivitas kehidupan sehari-hari seperti: memicu perselisihan, menimbulkan kesalahpahaman, mudah melakukan pelabelan dan dapat merenggankan hubungan sosial. Sedangakann karakteristik komunikasi interpersonal yang dikatakan menurut Wiryanto (dalam M. Yodiq, 2016) bahwa komunikasi interpersonal yang efektif maka dibutuhkan keterbukaan, empati, sikap, dukungan, rasa positif dan kesetaraan, kepercayaan diri, kesegeraan.

Rendahnya tingkat komunikasi interpersonal berkaitan dengan proses belajar atau kehidupan keluarga yang sulit, atau kejadian yang membuat tertekan. (Erlangga, 2017) menyatakan bahwa dalam kehidupannya perilaku manusia dipengaruhi oleh dua faktor utama, yaitu faktor internal dan faktor eksternal. Faktor internal semuanya bersumber dari dalam diri siswa tersebut: perhatian, kecerdasan, motivasi, sikap, pemikiran, 
316 Efektivitas Layanan Bimbingan Kelompok Berbasis Problem Based Learning untuk Meningkatkan Komunikasi Interpersonal Siswa - Rasimin, Affan Yusra, Hera Wahyuni

DOI: https://doi.org/10.31004/edukatif.v3i2.261

ingatan, kepercayaan diri, minat, bakat dan kepribadian. Faktor eksternal meliputi masyarakat, keluarga dan sekolah.

Salah satu masalah kemampuan komunikasi interpersonal di SMA Negeri 5 Kota Jambi yaitu bertanya dan berbicara di depan umum yang banyak dihadapi terutama pembelajaran. Kurangnya keterampilan komunikasi interpersonal sehingga mudah menimbulkan salah satu penyebab timbulnya kerenggangan hubungan antar siswa yang dapat meyebabkan salah satu bentuk masalah keterampilan komunikasi interpersonal yang rendah pada SMA Negeri 5 Kota Jambi yaitu bertanya dan berbicara dalam dihadapan umum yang banyak dihadapi terutama perkuliahan tatap muka. Keterampilan komunikasi interpersonal yang kurang sehingga mudah menyebabkan apapun sehingga menimbulkan kerenggangan hubungan antar siswa yang dapat memahami kesalahpahaman. Temuan di sekolah ini berbanding terbalik dengan yang di ungkapkan oleh devito (2013) menjelaskan beberapa aspek komunikasi: 1) empati, 2) penghargaan positif.

Bimbingan dan Konseling memiliki beberapa jenis layanan yang ditujukan kepada individu terutama dalam meningkatkan komuniksi interpersonal, salah satunya adalah layanan bimbingan kelompok. Kelompok layanan bimbingan belajar dapat membantu individu dalam melatih kemampuan berbicara yang baik. Prayitno dalam (Putri S.R:2017) dalam mengungkapkan masalah, memberikan pendapat dan penyelesaian masalah.

Kelompok layanan bimbingan memiliki teknik dan pendekatan dalam meningkatkan komuniksi interpersonal individu, salah satunya adalah pembelajaran berbasis masalah. (Rahmalia, Hajidin dan Bi, 2020) menjelaskan Hasil penelitiannya menunjukkan bahwa peningkatan kemampuan komunikasi matematis siswa dan disposisi matematis siswa dengan menerapkan model pembelajaran PBL lebih baik dari pada siswa yang menerapkan model pembelajaran konvensional.

Penggunaan PBL tidak hanya bisa diterapkan dalam pembelajaran dan layanan klasikal, namun didasari dari hasil penelitian yang dilakukan oleh Yusnia (2015) dia memanfaatkan metode PBL ini sebagai salah satu pendekatan dalam bimbingan kelompok dalam meningkatkan sikap tidak merokok. Dari hasil penelitiannya diperoleh bahwasanya pendekatan PBL dapat digunakan dalam meningkatkan sikap merokok hal ini ditunjukan terbagunya komunikasi yang positif dalam pelaksanaannya. Bimbingan pelaksanaan kelompok dilaksanakan dengan menggunakan berbagai teknik dan model pendekatan yang pada akhirnya dapat mencapai tujuan dari proses pembelajaran.

\section{METODE PENELITIAN}

Jenis penelitian adalah penelitian kuantitatif dengan rancangan penelitian eksperimen, menggunakan desain tes awal (pretest) dan perlakuan terakhir (posttest). Rancangan eksperimen yang digunakan dalam penelitian ini adalah rancangan eksperimen model Pre Experiment, dengan desain penelitian The One Group Pretest-Posttest. Yusuf (2013: 180) memaparkan bahwa rancangan ini terdiri dari satu kelompok (tidak ada kelompok kontrol), Nurhayati Abbas (Rahanra, 2020) menyatakan bahwa model pembelajaran berbasis masalah adalah model pembelajaran (problem based learning) dengan pendekatan pembelajaran siswa pada masalah otentik, sehingga siswa dapat mengarang sendiri, menumbuh mengembangkan keterampilan yang lebih tinggi, memandirikan siswa, dan meningkatkan komunikasi interpersonal. jadilah baik.

Penelitian ini didukung oleh hasil penelitian (Fijriani \& Rediska, 2017) yang berjudul "layanan bimbingan kelompok dalam meningkatkan komunikasi interpersonal. Dari hasi penelitian mereka dapat diperoleh bahwa layanan bimbingan belajar dapat meningkatkan komunikasi interpersonal berkenaan dengan metode penelitian yang digunakan quasi eksperimen oleh one postest preetest-group dengan 9 subjek penelitian. Berdasarkan hasil penelitian Subekti (2015) yang berjudul "Model Problem Based Learning dalam bimbingan dan konseling Meningkatkan Keterampilan Berpikir, adapun jumlah mata pelajaran dalam 
penelitian ini menggunakan metode Eksperimen dengan Desain Mata Pelajaran tunggal. Adapun yang dapat disimpulkan dalam penelitian ini: melalui penelitian tingkat berpikir kritis siswa dapat meningkatkan pembelajaran dan pembelajaran berbasis masalah dapat digunakan dalam pelaksanaan layanan bimbingan dan konseling. sedangkan proses penelitiannya dilaksanakan dalam tiga tahap yaitu; 1) melaksanakan pretest untuk mengukur kondisi awal responden sebelum diberikan perlakuan, 2) memberikan perlakuan, 3) melakukan postest untuk mengetahui keadaan variabel sesudah pemberian perlakuan.

Adapun yang menjadi populasi dalam penelitian ini adalah siswa kelas XII IPS SMAN 5 Kota Jambi. Teknik pengambilan sampel yang digunakan dalam penelitian ini adalah teknik purposive sampling. Mahasiswa yang menjadi subjek penelitian sebanyak 12 orang yang memiliki tingkat komunikasi interpersonal rendah hingga tinggi. Pengumpulan data dalam penelitian ini dilakukan dengan menggunakan instrumen berupa lembar observasi dan skala komunikasi interpersonal. Skala komunikasi interpersonal kemudian diuji validitasnya dan dibantu dengan reliabilitasnya program SPSS 21. Pengujian hipotesis untuk menguji Ha dalam penelitian ini menggunakan teknik analisis uji Wilcoxon. Perhitungan menggunakan program bantuan uji Wilcoxon program Microsoft Excel dan SPSS 201321 untuk windows.

\section{HASIL PENELITIAN DAN PEMBAHASAN}

Hasil perhitungan data sebelum dan sesudah adanya layanan bimbingan belajar kelompok perlakuan diimplementasikan dengan pendekatan Problem Based Learning pada Kelompok Eksperimen pada tabel di bawah ini:

Tabel 1. hasil pre-test dan post test-test

\begin{tabular}{c|c|c|c}
\hline $\begin{array}{c}\text { nama } \\
\text { siswa }\end{array}$ & $\begin{array}{c}\text { pretest } \\
\text { hasil }\end{array}$ & $\begin{array}{c}\text { Kenaikan } \\
\text { terjadi } \\
\text { (poin) }\end{array}$ & $\begin{array}{c}\text { Hasil } \\
\text { tes pasca }\end{array}$ \\
\hline 1 & 170 & 16 & 186 \\
\hline 3 & 122 & 46 & 168 \\
\hline 9 & 136 & 35 & 171 \\
\hline 11 & 135 & 43 & 178 \\
\hline 12 & 129 & 55 & 184 \\
\hline
\end{tabular}

Perubahan Terlihat antara pretest hasil post test dari skor setiap mata pelajaran. Pengalaman meningkatkan hasil pre-test dan post-test yaitu 39,5\%. Peningkatan persentase hasil pre test dan post test komunikasi dengan semakin meningkatnya keterbukaan didampingi siswa.

Hasil diatas menunjukkan bahwa peningkatan komunikasi interpersonal siswa dipengaruhi oleh pendekatan pembelajaran berbasis masalah, atau dengan kata lain pendekatan pembelajaran berbasis masalah komunikasi interpersonal efektif untuk meningkatkan siswa. Selanjutnya untuk mengetahui perbedaan hasil sebelum dan sesudah diperlakuan pada koleompok-circling, maka dilakukan pengujian hipotesis untuk menguji Ha dalam penelitian ini dengan menggunakan teknik analisis uji wilcoxon. 
Tabel 2. Hasil uji statistic dapat dilihat seperti yang ada pada table berikut:

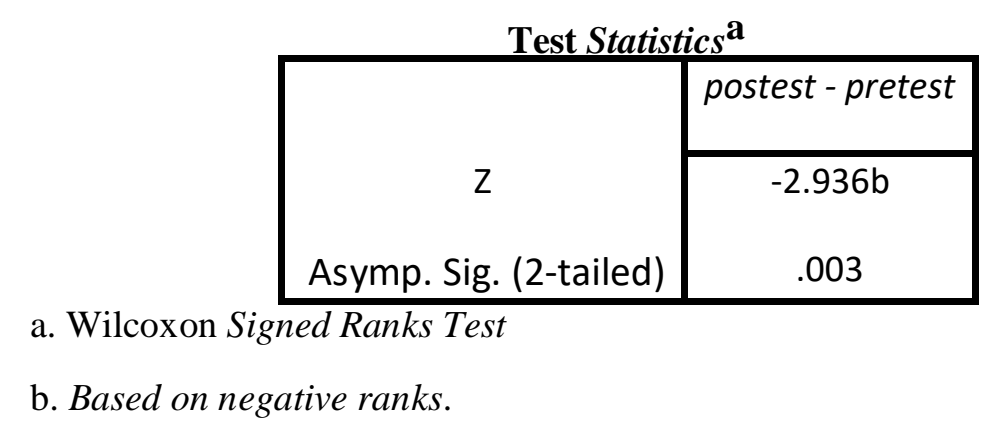

Peningkatan komunikasi interpersonal siswa kelas XII IPS 5 kota Jambi setelah diberikan pelayanan perlakuan melalui bimbingan kelompok berbasis masalah. pendekatan pembelajaran.

Berdasarkan hasil keluaran statistik Uji di atas dikenal Asymp. sig. (2-talailed) senilai 0,003. karena nilai yang lebih kecil dari 0,003 $<0,05$ Ha dapat disimpulkan maka diterima. Artinya terdapat perbedaan antara hasil pre dan post test, sehingga dapat disimpulkan bahwa ada perubahan atau peningkatan komunikasi interpersonal siswa kelas XII IPS SMA Negeri 5 Kota Jambi setelah diberikan pelayanan perlakuan. melalui pendekatan bimbingan kelompok untuk pembelajaran berbasis masalah.

Perbedaan tingkat komunikasi interpersonal siswa setelah pretes dan postes serta mandiri reguler dipengaruhi oleh banyak faktor. Supratiknya (Awi dkk, 2016) menunjukkan beberapa peran komunikasi interpersonal disumbangkan dalam rangka menciptakan kegembiraan hidup manusia, yaitu sebagai berikut; Komunikasi antarpribadi 1) membantu perkembangan sosial dan intelektual kita; 2) identitas dan identitas kita dibentuk dalam dan melalui komunikasi dengan orang lain; 3) untuk menguji realita di sekitar kita dan menguji kebenaran kesan dan pemahaman yang kita miliki tentang dunia di sekitar kita, kita perlu membandingkannya dengan kesan dan pemahaman orang lain tentang realitas yang sama; 4) Kesehatan mental kita juga sangat ditentukan oleh kualitas komunikasi atau relasi kita dengan orang lain, semakin banyak pula orang yang menjadi figur penting (figur penting) dalam hidup kita.

Maka dalam penelitian ini siswa kelas XII IPS SMA Negeri 5 Kota Jambi pada waktu pretes siswa dalam kategori komunikasi interpersonal sedang dan siswa kelas XII IPS SMA State 5 Kota Jambi tepat waktu. Siswa pre-test dalam kategori sedang memiliki rata-rata komunikasi interpersonal dalam kategori tinggi. Rata-rata skor komunikasi interpersonal sebelum pre-test berkisar 144 sedangkan setelah post-test 183 atau meningkat 39,5\%. Maka dapat disimpulkan bahwa terdapat perbedaan siswa kelas XII IPS SMA statet 5 kota Jambi setelah diadakan pre test, treatment dan seterusnya post test mengalami peningkatan komunikasi interpersonal yang signifikan. Effendy (dalam Suharsono, 2005) menyatakan "komunikasi interpersonal adalah penyampaian pesan oleh satu orang dan penerimaan pesan oleh orang lain atau sekelompok kecil orang, dengan dampak yang berbeda dan dengan kesempatan untuk memberikan umpan balik segera". Dalam proses komunikasi adalah pertukaran informasi antara seseorang dengan paling sedikit satu atau yang lainnya biasanya antara dua orang yang dapat langsung diketahui inversnya.

Hal ini juga sejalan dengan penelitian yang dilakukan oleh Munawaroh \& M.Rajab (2015) menjelakan dari hasil penelitian mereka komunikasi interpersonal dapat digunakan dalam meningkatkan komunikasi interpersonal dengan teknik sosiodrama, adapun hasilnya sebagai berikut tindakan siklus I terjadi peningkatan Komunikasi siswa menjadi 5 orang siswa sudah memiliki keterampilan komunikasi interpersonal tinggi, 4 orang siswa memiliki komunikasi interpersonal cukup, dan 1 orang siswa memiliki komunikasi interpersonal 
rendah yakni mengalami peningkatan $76 \%$. Setelah tindakan siklus II peningkatan juga terjadi menjadi 8 orang siswa memiliki keterampilan komunikasi interpersonal tinggi dan 1 orang yang memiliki komunikasi interpersonal cukup yakni mengalami peningkatan $86 \%$.

aspek penting komunikasi interpersonal bagi siswa yang harus mereka kuasai. Dalam melaksanakan komunikasi dibutuhkan keterampilan dalam menjalin komunikasi interpersonal yang begitu tinggi. Selanjutnya yang memiliki kekampuan interpersonalnya komunikasi yang dominan rendah seringkali dirasa kurang dalam komunikasi terbuka, menunjukkan sikap yang baik dalam berkomunikasi. dari penjelasan yang telah anda uraikan semoga dapat disimpulkan bahwa terdapat perbedaan komunikasi interpersonal siswa XII IPS SMA statet 5 kota Jambi setelah pre test, tes perlakuaan dan pasca terjadi perubahan signifikansi.

\section{KESIMPULAN}

Berdasarkan pelaksanaan penelitian tentang efektivitas pelayanan konseling kelompok dengan pendekatan pembelajaran berbasis masalah, maka dari hasil penelitian dapat disimpulkan bahwa pendekatan pembelajaran berbasis masalah dapat meningkatkan komunikasi interpersonal siswa. Terdapat perbedaan tingkat keefektifan pendekatan problem based learning dalam meningkatkan komunikasi interpersonal siswa yang di tunjukanya adanya perbedaan sebelum dan sesudah diberikan perlakuan.

Berdasarkan musyawarah dan kesimpulan, suatu tujuan ditujukan pada pemangku kepentingan pada khususnya; 1) Bagi konselor sebagai bahan masukan dalam pelaksanaan layanan bimbingan dan konseling secara efektif dan efisien, khususnya dalam penggunaan layanan bimbingan belajar berbasis kelompok pendekatan program untuk meningkatkan komunikasi interpersonal mahasiswa; 2) Untuk Mata Kuliah Bimbingan dan Konseling Fakultas Pendidikan Universitas Jambi, dalam rangka mempersiapkan calon guru dan calon pembimbing untuk pemberian materi, serta konsep dalam pendekatan pembelajaran berbasis program untuk meningkatkan komunikasi interpersonal mahasiswa; 3) Hasil penelitian diharapkan dapat memberikan kontribusi terhadap pengembangan teori tentang efektifitas program pembelajaran berbasis kelompok layanan bimbingan belajar untuk meningkatkan komunikasi interpersonal komunikasi interpersonal mahasiswa.

\section{UCAPAN TERIMA KASIH}

Penulis mengucapkan terima kasih yang tak terhingga kepada Rektor Universitas Jambi dan Dekan Fakultas Keguruan dan Ilmu Pendidikan Universitas Jambi yang telah membiayai penelitiannya melalui Checklist Pelaksana Anggaran Fakultas Keguruan dan Ilmu Pendidikan. dan ilmu kependidikan Universitas Jambi, maka kami ucapkan banyak terima kasih kepada Kepala Bidang Pembinaan dan Konseling Fakultas Keguruan dan Ilmu Pendidikan Universitas Jambi yang telah membantu memfasilitasi dalam Administrasi dan mendukung terlaksananya secara penuh kegiatan tersebut di agar bisa berjalan dengan maksimal. Selanjutnya terimaksih kita ucapkan salam kepada kepala sekolah SMA Negeri 5 Kota Jambi beserta Koordinator Bimbingan dan Konseling yang terlibat dalam penelitian ini yang telah bersedia memberikan izin untuk dapat terlaksannya penelitian ini agar dapat berjalan lancar, selanjutnya penulis mengucapkan terimakasih kepada siswa kelas XII IPS SMA Negeri 5 Kota Jambi yang telah berpartisipasi dan berkontribusi dalam penelitian ini. 
320 Efektivitas Layanan Bimbingan Kelompok Berbasis Problem Based Learning untuk Meningkatkan Komunikasi Interpersonal Siswa - Rasimin, Affan Yusra, Hera Wahyuni

DOI: https://doi.org/10.31004/edukatif.v3i2.261

\section{DAFTAR PUSTAKA}

Kemendikbud. (2013). Materi Pelatihan Guru Melaksanakan Kurikulum 2013. Jakarta: RI Kemendikbud.

Putri, S. R. (2017). Pengaruh Konseling Kelompok terhadap Penurunan Masalah Diri Pribadi Siswa SMA Negeri 6 Padang. Jurnal Penelitian Bimbingan dan Konseling, 2(1).

Subekti, L. (2015). Model Problem Based Learning Dalam Layanan BK Untuk Meningkatkan Keterampilan Berpikir Kritis. Didaktikum, 16(1).

Siddik, H. (2016). Hakikat Pendidikan Islam. Al-Riwayah: Jurnal Kependidikan, 8(1), 89-103.

Yodiq, M. (2016). Peran Komunikasi Interpersonal Kepala Sekolah terhadap Motivasi Kerja Guru di Sekolah Menengah Atas Islam Samarinda. Jurnal Ilmu Komunikasi, 4(2), 25.

Fijriani, F., \& Amaliawati, R. (2017). Layanan bimbingan kelompok dalam meningkatkan komunikasi interpersonal siswa. TERAPUTIK: Jurnal Bimbingan dan Konseling, 1(1), 24-32.

Rahmalia, R., Hajidin, H., \& Ansari, B. I. (2020). Peningkatan Kemampuan Komunikasi Matematis dan Disposisi Matematis Siswa SMP Melalui Model Problem Based Learning. Numeracy, 7(1), 137149.

Suharsono, S. (2020). Komunikasi Interpersonal Pokdarwis Dalam Meningkatkan Kualitas Pelayanan Homestay. Jurnal Riset Komunikasi, 3(2), 161-176.

Awi, M. V., Mewengkang, N., \& Golung, A. (2016). Peranan Komunikasi Antar Pribadi Dalam Menciptakan Harmonisasi Keluarga Di Desa Kimaamkabupaten Merauke. Acta Diurna Komunikasi, 5(2).

Rahanra, R. M., \& Runtuboi, O. (2020). Pengaruh Pembelajaran Pbl (Problem Base Learning) Dengan Media Gambar Pada Pokok Bahasan Sistim Pencernaan Di Kelas X SMA PGRI SERUI PROVINSI PAPUA. Biolearning Journal, 7(2), 56-60.

Erlangga, E. (2017). Bimbingan Kelompok Meningkatkan Keterampilan Berkomunikasi Siswa. PSYMPATHIC: Jurnal Ilmiah Psikologi, 4(1), 149-156.

Yusnia, I. (2015). Meningkatkan Sikap Tidak Merokok Melalui Layanan Bimbingan Kelompok Dengan Model PBL. Jurnal Penelitian Tindakan Bimbingan \& Konseling, 1(2).

Lubis, M. R. (2015). Meningkatkan keterampilan komunikasi interpersonal siswa melalui layanan bimbingan kelompok teknik sosiodrama kelas VIII MTSN 2 Medan. Jurnal Diversita, 1(2).

Khodijah, S. (2018). Strategy for Increasing The Students' Interpersonal Communication Skills through Problem-Based Learning. International Journal of Educational Research Review, 3(4), 150-158. 